\title{
Ginger ameliorates reproductive toxicity of formaldehyde in male mice: Evidences for Bcl-2 and Bax
}

\author{
Ali Soleimanzadeh ${ }^{*}{ }^{\mathbb{D}}$, Mahdieh Pourebrahim $^{1}$, Nowruz Delirezh ${ }^{2}$, Mehdi Kian $^{1}$ \\ ${ }^{1}$ Department of Theriogenology, Faculty of Veterinary medicine, Urmia University, Urmia, Iran \\ ${ }^{2}$ Department of Immunology and Microbiology, Faculty of Veterinary medicine, Urmia University, Urmia, Iran
}

\section{A R T I C L E I N F O}

Article Type:

Original Article

Article History:

Received: 9 March 2018

Accepted: 28 August 2018

\section{Keywords:}

Formaldehyde

Zingiber officinale

Oxidative stress

Gene expression

Medicinal plants

\begin{abstract}
A B S T R A C T
Introduction: Root of dietary ginger considerably improves the activity of antioxidant enzymes in reproductive system and reduces the signs of cell damage in testis tissues. The present study conducted numerous sperm, hormonal, bio-chemical analysis and gene expression in order to evaluate the reproductive damages caused by exposure to formaldehyde (FA) and to investigate the ameliorative properties of co-administration of FA and Zingiber officinale (Ginger) in mice model.

Methods: Forty-eight male NMRI mice were randomized into 6 groups of 8 animals each, including control group, control sham (received distilled water by gavage), FA group (10 mg/ $\mathrm{kg}$ twice per day), intraperitoneally (i.p) and 3 FA groups (10 mg/kg i.p) + Ginger (500, 1000 and $2000 \mathrm{mg} / \mathrm{kg} / \mathrm{d}$ by gavage, respectively). Sperm parameters, sexual hormones, antioxidant activity and expression of Bax and Bcl-2 genes were analyzed after 35 days.

Results: FA significantly diminished sperm parameters, sexual hormones and antioxidant enzymes $(P<0.05)$. Also, the expression of $B c l-2$ and Bax genes had significant $(P<0.05)$ increase and decrease, respectively in FA group. Co-administration of Ginger extract significantly recovered the above parameters.

Conclusion: Co-administration of Ginger extract ameliorates reproductive damages of FA by its androgenic, antioxidant and anti-apoptotic properties. Hence, it might be beneficial in these patients.
\end{abstract}

Implication for health policy/practice/research/medical education:

Ginger significantly ameliorates oxidative stress induced by formaldehyde toxicity in male reproductive system, therefore, this herb could be used as a natural source for inventing new drugs to cure male infertility.

Please cite this paper as: Soleimanzadeh A, Pourebrahim M, Delirezh N, Kian M. Ginger ameliorates reproductive toxicity of formaldehyde in male mice: Evidences for Bcl-2 and Bax. J Herbmed Pharmacol. 2018;7(4):259-266. doi: 10.15171/jhp.2018.39.

\section{Introduction}

Recent studies have revealed evidences on the harmful effects of environmental contaminants on male fertility $(1,2)$. Formaldehyde $\left(\mathrm{FA}, \mathrm{CH}_{2} \mathrm{O}\right)$ is a flammable, colorless and pungent chemical agent which is highly used in industries, hospitals, scientific labs and households (3). It is considered as one of the most important chemical compounds in global economy. Widespread usage of FA has been increased its environmental or occupational exposure (4,5). Reproductive system is negatively influenced by FA, so that it decreases sperm parameters including count, viability, motility, and morphology of sperms $(6,7)$. Exposure to FA causes testicular toxicity by diminishing activity of antioxidant enzymes and increasing lipid peroxidation, therefore it induces oxidative stress in testes (8-12). FA also damages spermatogenetic cells and increases synthesis of Hsp70 and Bax gene expression in testis tissue $(9,13)$.

The main mechanism of FA toxicity is by induction of DNA-protein crosslinks which activates p53 factor and pro-apoptotic gene targets (14). According to numerous studies, using antioxidants can prevent oxidation-induced cell damage improving sperm quality and reproductive functioning $(15,16)$.

Ginger (Zingiber officinale Roscoe, Family: Zingiberacae) is widely used as a spice in many countries, especially in the South-Eastern Asian countries. Due to the therapeutic properties of ginger rhizomes, many physicians utilize it 
as a medicinal plant (17). Also, because of the existence of antioxidant compounds such as zingerone, zingibrence, gingerol, glucosides-6-gingerdiol, volatile oils and flavonoid substances in Ginger, it is classified as a strong antioxidant plant. The compounds found in Ginger are able to scavenge free radicals, hence Ginger can prevent peroxidation induced by free radicals in cellular structure $(18,19)$.

Ginger exhibits pro-fertility properties in male animal models (20). Administration of Ginger considerably increases the percentage of sperm viability and motility and also concentration of serum total testosterone. Hence, it can be used to improve sperm quality (19). Root of dietary ginger considerably improves the activity of antioxidant enzymes and malondialdehyde (MDA) level in the reproductive system and also reduces the signs of cell damage in testis tissues $(11,18)$.

The present study conducts numerous sperm, hormonal, bio-chemical analysis and gene expression in order to evaluate the reproductive damages caused by exposure to FA and to investigate the ameliorative properties of coadministration of FA and Ginger in mice model.

\section{Materials and Methods}

Ginger extract preparation

Ginger rhizomes were obtained from an herbal store in Urmia, Iran. One hundred grams of grinded dried Ginger rhizomes were added to $1000 \mathrm{~mL}$ of $96 \%$ ethanol and water (50:50) solution for $72 \mathrm{hr}$. Gauze and Whatman filter (No. 40) was used to filter the extract. Later, using a rotary evaporator, ethanol was evaporated at $40^{\circ} \mathrm{C}$ under vacuum.

\section{Animals}

Adult male NMRI mice at the age of 6-8 weeks old and weighting $30 \pm 2 \mathrm{~g}$ were obtained from the animal house of Urmia University of Medical Sciences (Urmia, Iran). They received a pellet diet and tap water ad libitum. The animals were kept in polycarbonate cages with woodchip bedding under 12:12 h light/dark cycle. The room temperature and humidity were $22 \pm 2^{\circ} \mathrm{C}$ and $50 \pm 10 \%$, respectively. They were kept for 2 weeks to acclimatize before using them for experimental purposes.

\section{Experimental design}

Animals were randomly categorized into six groups $(n=8)$. Group I was chosen as the control group. Group II was the sham group and received $0.2 \mathrm{~mL}$ distilled water by gavage. Group III intraperitoneally received $10 \mathrm{mg} / \mathrm{kg}$ of FA twice a day. Group IV received Ginger $(0.5 \mathrm{~g} / \mathrm{kg} / \mathrm{d})$ by gavage and also FA at dose of $10 \mathrm{mg} / \mathrm{kg} / \mathrm{d}$, intraperitoneally. Group V received ginger at dose of $1 \mathrm{~g} / \mathrm{kg} / \mathrm{d}$, by gavage and FA at dose of $10 \mathrm{mg} / \mathrm{kg}$ twice per day, i.p. Group VI received ginger at dose of $2 \mathrm{~g} / \mathrm{kg} / \mathrm{d}$, by gavage and FA at dose of $10 \mathrm{mg} / \mathrm{kg}$ twice per day, i.p. FA and Ginger were simultaneously administrated in groups IV to VI. The doses of Ginger and FA administrated to animals were chosen based on Rong et al (21) and Tajaddini Mahani et al (7) studies, respectively.

\section{Sampling of serum and collecting tissue}

The mice were decapitated under anesthesia after 35 days. Their blood was transferred into laboratory tubes and centrifuged for 10 minutes at the rate of $3000 \mathrm{rpm}$. The serum was obtained and frozen at $-20^{\circ} \mathrm{C}$ for biomedical experiments after aliquoting into micro tubes. The right testes of the mice were obtained from all groups and stored at $-20^{\circ} \mathrm{C}$ in order to analyze the testicular enzyme activity.

\section{Epididymal sperm analysis}

In order to obtain the epididymal sperm content of the mice, the tails of epididymes were excised and minced to small pieces and put into a Petri dish contained $1 \mathrm{~mL}$ of pre-heated HTF (human tubal fluid) medium ( $\mathrm{pH}=7.4$ ). The Petri dishes were put in incubator for 20 minutes at $37^{\circ} \mathrm{C}$ to let the sperms swim out from epididymis. HTF medium was used to dilute the sperm suspension (1:20). Sperm parameters were analyzed based on WHO laboratory manual for the examination and processing of human semen (22).

\section{Sperm motility}

A phase contrast microscope (BC41, Olympus Co., Japan) was utilized in order to analyze a drop of sperm suspension. A minimum of ten fields were noticed in 400X magnification in order to determine the sperm motility percentage.

\section{Sperm count}

Hemocytometer (HBG, Germany) was used to specify the sperm concentration. About $10 \mu \mathrm{L}$ of sperm solution was put in the chambers of hemocytometer and left for 5 minutes in order to impede drying. The settled sperms were moved to a phase contrast microscope and analyzed under 400X magnification and the sperm count was stated by " $\mathrm{n} x 50000 \mathrm{x}$ d" formula, in which $\mathrm{n}$ is the count and $\mathrm{d}$ is the dilution solution.

Sperm morphology and viability

Eosin nigrosine stain and the suspension of diluted sperm were combined in an equal volume. The stained mixture was spread on clean slides and air-dried. The obtained sperms were analyzed by a phase contrast microscope (400X). The viability percentage calculation was conducted by scoring 200 sperm cells per mouse. The unstained sperms were alive and the color of the dead ones turned red. The experiment was conducted in a minimum of 10 fields in order to determine the live sperm percentage. The slides were also observed under 400X magnification in order to determine the morphological anomalies of sperms. The anomalies included amorphous shape, not having hook, bicephalic, coiled or abnormal 
tails. About 200 sperms were inspected in each mouse via the microscope (23).

\section{Teratozoospermia index}

Teratozoospermia index (TZI) expresses the number of anomalies per each abnormal sperm. Depending on the numbers of anomalies of each sperm in different parts (head, neck and/or tail), values of TZI are between 1-3. To obtain TZI, total of anomalies were divided by the number of abnormal spermatozoa as described by Krassas et al. (24).

\section{DNA fragmentation}

Staining with acridine orange $(\mathrm{AO})$ was utilized to assess sperms DNA fragmentation. Carnoy' fixative (methanol/ acetic acid 3:1) was used to fix smears and they were placed in the fixative for two hours. After removing from the fixative, they were left intact at room temperature in order to be dried. Then, slides were put in a stock solution containing $1 \mathrm{mg} \mathrm{AO}$ and $1000 \mathrm{~mL}$ distilled water. The solution was placed in a dark place with the temperature of $4^{\circ} \mathrm{C}$. Meanwhile, the stained solution was prepared containing a mixture of $10 \mathrm{~mL}$ stock and $40 \mathrm{~mL}$ of 0.3 $\mathrm{M} \mathrm{NaHPO} .7 \mathrm{H}_{2} \mathrm{O}$ solution. Fluorescent microscope was used for the analysis of the sperms following staining for 5 minutes. Normal sperms were green and the yellowred sperms were classified as anomalous. Finally, the percentage of sperms having green and orange/red fluorescence were determined (25).

\section{Hormonal assays}

Testosterone's serum levels were analyzed by ELISA based on the manual provided by the manufacturer's kit (Diablast Co., USA).

Commercial kits (Amersham, Buckinghamshure, UK) were used to determine serum LH and FSH by ELISA according to previous studies (26).

\section{Antioxidant activity and lipid peroxidation}

Ferric reduction antioxidant power assay (FRAP) was used to determine the total antioxidant capacity of the semen (27). One microliter of FRAP reagent (Trtipiridyl triazine; Merck, Germany) was mixed with $100 \mu \mathrm{L}$ of cellular supernatant and incubated for 10 minutes in $37^{\circ} \mathrm{C}$ in dark environment. The blue-colored reagent was read at $595 \mathrm{~nm}$ in 20 seconds interval for 10 minutes. FeII (FeSO4.7H2O) solution was selected as blank solution and concentration of ascorbic acid was taken as standard solution.

Following defrosting the right testes, soft tissue homogenizer (Omni International, USA) was used to homogenize the testicular tissue into 9 volumes of ice cooled $0.9 \%$ buffer saline solution. Later, it was centrifuged for 10 minutes at the rate of $4000 \mathrm{x} g$ at $4^{\circ} \mathrm{C}$ and the resulting supernatant was taken to estimate lipid peroxidation and functioning of antioxidant enzymes.
The method used by Placer et al was used to determine the yield of lipid peroxidation MDA and Rajesh and Latha's method (28) was used to estimate the content of reduced glutathione (GSH). The methods proposed by Nishikimi et al (29), Paglia and Valentine (30) and Sinha (31) were utilized to analyze the functioning of various enzymes acting as antioxidant such as superoxide dismutase (SOD), glutathione peroxidase (GPx) and catalase (CAT), respectively.

\section{Isolation of RNA}

Based on the manual provided by the manufacturer, RNX plus solution (Cinnagen, Iran) was used to isolate the total RNA for the testis. One microliter of RNX solution was added to homogenize the tissue and left intact in the room temperature for 5 minutes. Later, $200 \mu \mathrm{L}$ chloroform was added to the tube and centrifuged for 15 minutes at the rate of $12000 \mathrm{~g}$ at $4 \mathrm{P}$ o PC. RNA was obtained from the solution and an equal amount of isopropanol was added to it. The resulting compound was placed in the centrifuge with the rate of $12000 \mathrm{~g}$, at $4 \mathrm{P}$ o $\mathrm{PC}$ for 10 minutes. $75 \%$ ethanol was used to rinse the pellet and suspended again in $50 \mu \mathrm{L}$ of diethylpyrocarbonate (DEPC) treated water. Absorbance ratio A260/A280 nm was used to evaluate RNA quantity and its integrity was measured by $1 \%$ agarose gel electrophoresis.

\section{cDNA synthesis for real-time RT-PCR}

cDNA Synthesis Kit Revert Aid was obtained from the Fermentas Corporation (Germany). One microgram of RNA was reverse transcribed with $5 \mathrm{X}$ Reaction Buffer, 20 $\mathrm{U} / \mu \mathrm{L}$ Ribolock RNase inhibitor, $10 \mathrm{mM}$ dNTP, $200 \mathrm{U} / \mu \mathrm{L}$ MMLV reverse transcriptase, and oligo (dt) 18 primer in a $20 \mu \mathrm{L}$ reaction in order to synthesize cDNA. The resulting combination was incubated for 60 minutes in $42^{\circ} \mathrm{C}$. Later, the enzyme was inactivated for 5 minutes at $70^{\circ} \mathrm{C}$.

\section{Real-time RT-PCR}

RT-PCR was used to specify the levels of Bcl-2 and Bax transcripts using SinaClon (Tehran, Iran). In order to normalize the input load of cDNA, 18SrRBA was chosen as a house-keeping gene. Nucleotide sequence of GenBank was used as the basis of PCR primers for finding the Bax, 18SrRNA and Bcl-2 genes in the mitochondrial genome of mice. The nucleotide sequences of the primer pair chosen for $18 S r R N A$ were as follows: 5' - TGCGGAAGGATCATTAACGGA-3' and reverse, 5'AGTAGGAGAGGAGCGAGCGACC-3' with amplified product of expected $300 \mathrm{bp}$. The sequences selected for $\mathrm{Bcl}-2$ were as follows: forward, 5'-TACCGTCGTGACTTCGCAGAG-3' and reverse, 5'-GGCAGGCTGAGCAGGGTCTT-3' with amplified product of expected $350 \mathrm{bp}$. The nucleotide sequences of the primer pair selected for Bax were as follow: forward, 5' - CGGCGAATTGGAGATGAACTG-3' and reverse, 5' - GCAAAGTAGAAGAGGGCAACC-3'. These 
primers yielded a 160 bp product. Hot Taq (cat\# BT 11101- SinaClon, Iran) was used for conducting PCR (RTqPCR) analysis. One microliter of cDNA was combined with a mixture of $1 \mu \mathrm{M}$ of each primer and $4 \mu \mathrm{L}$ of Hot Taq Eva Green Ready Mix (SinaClon, Iran) and the total amount reached $25 \mu \mathrm{L} .1 .5 \%$ agarose gel electrophoresis was conducted on an aliquot of each reaction mixture. Reaction condition was $95^{\circ} \mathrm{C}$ for 15 minutes, 40 cycles of $95^{\circ} \mathrm{C}$ for 15 seconds, $62^{\circ} \mathrm{C}$ for 60 seconds, and $70^{\circ} \mathrm{C}$ for 20 seconds. The amplification of PCR was conducted for 3 times for each sample by using Bcl-2, Bax, and 18SrRNA (32).

The obtained standard curve data were used to measure the efficacy of PCR amplification of $B c l-2, B a x$ and 18SrRNA. The value of cycle threshold (CT) for the target genes (Bcl-2 and Bax) were normalized according to the reference gene (18SrRNA), and $\Delta \Delta \mathrm{CT}$ model was used to conduct relative quantification. Melting curve analysis was done following the RT-PCR in order to ensure the homogeneity of the product.

Statistical analysis

All values were presented as the mean \pm standard deviation (SD). Differences between mean values were compared using SPSS 17.0 (Chicago, USA) by one-way analysis of variance (ANOVA) test followed by Tukey post hoc. $P<$ 0.05 was considered as statistically significant.

\section{Results}

Sperm parameters

Table 1 shows parameters including sperm count, viability, motility, morphology, TZI, and DNA fragmentation. A significant decrease was seen in FA group in comparison to other groups. Simultaneous administration of FA along with Ginger reduced the decrease in parameters of sperm in comparison to FA group. Hence, using Ginger leads to a decrease in sperm parameters but it is not comparable to that of control sham and sham groups (Figures 1 and 2).

Hormonal assays

Mean serum concentration of sexual hormones (testosterone, luteinizing hormone $[\mathrm{LH}]$ and folliclestimulating hormone $[\mathrm{FSH}]$ ) are shown in Table 2. FA group exhibited a significant decrease in hormonal concentration in comparison to other groups. It should be noted that the group receiving Ginger had a considerable increase dependent on the dosage, but it could not reach to control sham and control groups.

Antioxidant activity and lipid peroxidation

FA group had experienced a considerable decrease in antioxidant activity. The groups receiving Ginger and FA had higher antioxidant activity in comparison to FA group (Table 3). FA groups also showed a considerable increase of MDA but it decreased in Ginger + FA groups dependent on the dose (Table 4).

\section{Real-Time PCR}

As it is obvious in Table 5, Bcl-2 expression was considerably lower in comparison to control and other groups, but it had incremental in Ginger + FA groups. FA group showed a considerable increase in Bax gene expression while Ginger + FA groups had significant decreases (Figure 3).

\section{Discussion}

In this study damages caused by exposure to FA and ameliorative effects of co-administration of Ginger with FA were demonstrated by evaluation of sperm parameters,

Table 1. Comparison of sperm parameters in different groups

\begin{tabular}{|c|c|c|c|c|c|c|}
\hline & Control & FA & Sham & Ginger 0.5 + FA & Ginger 1 + FA & Ginger 2+ FA \\
\hline Sperm count $\left(10^{6}\right)$ & $22.43 \pm 0.54^{a}$ & $12.09 \pm 0.76^{b}$ & $22.65 \pm 0.34^{c}$ & $16.22 \pm 1.38^{d}$ & $21.28 \pm 0.41^{\mathrm{e}}$ & $21.31 \pm 0.56^{e}$ \\
\hline Sperm motility (\%) & $78.30 \pm 1.08^{a}$ & $64.36 \pm 1.24^{b}$ & $76.78 \pm 1.34^{c}$ & $67.22 \pm 1.06^{d}$ & $70.57 \pm 1.45^{e}$ & $71.14 \pm 1.34^{f}$ \\
\hline Sperm viability (\%) & $86.33 \pm 0.99^{a}$ & $69.56 \pm 1.20^{\mathrm{b}}$ & $85.35 \pm 0.83^{c}$ & $73.35 \pm 1.44^{d}$ & $78.47 \pm 0.81^{\mathrm{e}}$ & $78.87 \pm 1.05^{f}$ \\
\hline Sperm morphology (\%) & $91.31 \pm 1.33^{\mathrm{a}}$ & $79.63 \pm 0.89^{b}$ & $91.12 \pm 1.12^{\mathrm{a}}$ & $82.99 \pm 1.22^{\mathrm{c}}$ & $86.50 \pm 1.36^{d}$ & $86.56 \pm 0.68^{d}$ \\
\hline DNA fragmentation (\%) & $2.11 \pm 0.86^{a}$ & $16.53 \pm 0.84^{b}$ & $2.32 \pm 0.77^{a}$ & $13.58 \pm 0.80^{c}$ & $7.52 \pm 0.91^{d}$ & $7.18 \pm 0.69^{d}$ \\
\hline Teratozoospermia index & $1.05 \pm 0.42^{\mathrm{a}}$ & $1.94 \pm 0.60^{\mathrm{b}}$ & $1.06 \pm 0.58^{\mathrm{a}}$ & $1.89 \pm 0.46^{b}$ & $1.54 \pm 0.51^{c}$ & $1.32 \pm 0.47^{d}$ \\
\hline
\end{tabular}

Abbreviation: Fa, formaldehyde.

Different letters indicate significant differences $(P<0.05)$ between groups. Values represent means \pm SEM $(N=8)$.

Table 2. The serum mean concentrations of sexual hormones in different groups

\begin{tabular}{|c|c|c|c|c|c|c|}
\hline & Control & FA & Sham & Ginger 0.5 + FA & Ginger 1 + FA & Ginger 2+ FA \\
\hline Testosterone $(\mu \mathrm{mol} / \mathrm{L})$ & $7.18 \pm 0.18^{a}$ & $4.43 \pm 0.25^{b}$ & $6.90 \pm 0.08^{c}$ & $4.98 \pm 0.29^{d}$ & $5.74 \pm 0.17^{e}$ & $5.96 \pm 0.30^{f}$ \\
\hline $\mathrm{LH}(\mathrm{mIU} / \mathrm{ml})$ & $2.59 \pm 0.66^{a}$ & $0.66 \pm 0.23^{b}$ & $2.55 \pm 1.44^{\mathrm{a}}$ & $0.93 \pm 0.44^{b}$ & $1.351 \pm 1.32^{c}$ & $1.81 \pm 1.27^{d}$ \\
\hline FSH (mIU/ml) & $3.63 \pm 1.49^{a}$ & $1.27 \pm 1.18^{\mathrm{b}}$ & $3.62 \pm 1.33^{\mathrm{a}}$ & $1.39 \pm 0.79^{c}$ & $1.92 \pm 1.25^{d}$ & $2.50 \pm 1.56^{e}$ \\
\hline
\end{tabular}

Abbreviation: Fa, formaldehyde.

Different letters indicate significant differences $(P<0.05)$ between groups. Values represent means \pm SEM $(N=8)$. 


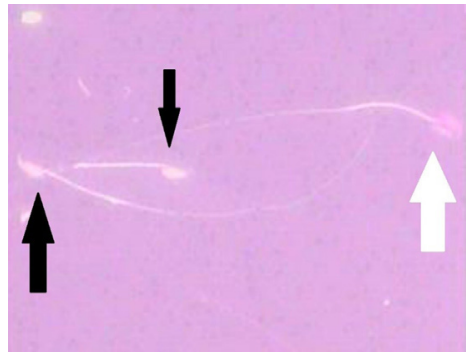

Figure 1. Sperm viability; Dead sperm stained red (White arrow) and viable sperms are colorless (Black arrows); (Eosin/nigrosin, 1000×).

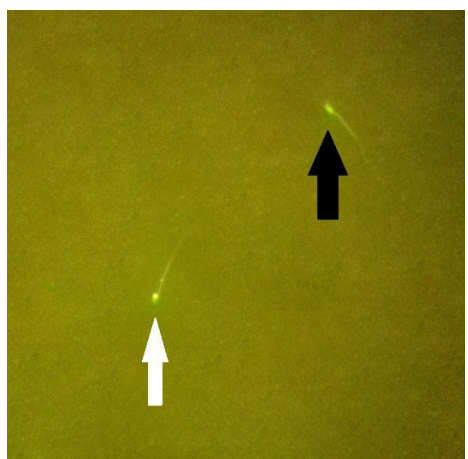

Figure 2. Mice spermatozoa; Normal sperm stained green (Black arrow) and damaged DNA stained yellow (White arrow); (AO, 400×).

sexual hormones, antioxidant activity, lipid peroxidation and gene expression of apoptotic and anti-apoptotic factors.

The reduction of sperm quality in the present study indicates negative effects of oxidative stress induced by FA on male reproductive system. Several other studies have indicated the adverse effects of FA on sperm parameters $(6,7,33,34)$ and our study is in line with them. FA has ability to cross the blood-testis barrier and induces oxidative stress by producing ROS which leads to degeneration

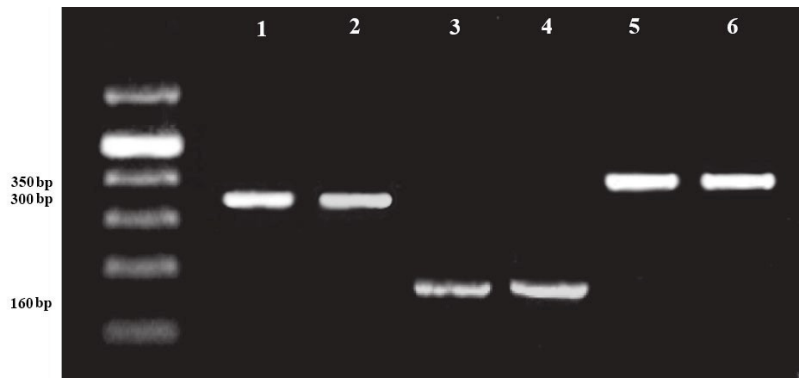

Figure 3. Effects of Ginger/FA on the expression of: (Lane 1-2) 18SrRNA (300 bp), (Lane 3-4) Bax (160 bp) and (Lane 5-6) Bcl-2 (350 bp) at mRNA level.

of germ cells and disruption of spermatogenesis $(6,33)$. Exposure to FA also initiates autophagy in testis which is related to spermatogenetic failure and germ cells death (35). FA decreased Tsga10 which is correlated with quality of sperm parameters, especially morphology and motility rates (7). Exposure to FA also decreases number of Leydig cells in testes $(6,13)$. Henkel et al (36) demonstrated a direct correlation between sperm motility and decline in Leydig cells. A direct relationship between the FA exposure and dispersion of DNA chromatin of sperm was found by Betancourt-Martínez et al (34).

In this research, Ginger extract improved sperm parameters when administrated simultaneously with FA. This results confirm previous reports $(19,20,37-39)$. It might be due to Ginger could prevent from apoptosis or/ and due to decrease of ROS in testis tissue. Mohammadi et al (38) indicated that Ginger extract could cause a significant increase in Sertoli cells. Therefore, the increase in Sertoli cells might be one reason for the significant improvement of spermatogenesis.

Similar to other studies $(6,8,11,13)$, in this study FA exposure reduced levels of testosterone in serum. It might be consequence of $\mathrm{LH}$ decrement, because $\mathrm{LH}$

Table 3. The mean amounts of antioxidant activity in different groups

\begin{tabular}{lllllll}
\hline & Control & FA & Sham & Ginger 0.5 + FA & Ginger 1+ FA & Ginger 2+ FA \\
\hline TAC ( $\mu \mathrm{mol} / \mathrm{L})$ & $1.95 \pm 0.36^{\mathrm{a}}$ & $0.77 \pm 0.23^{\mathrm{b}}$ & $1.85 \pm 0.08^{\mathrm{c}}$ & $0.95 \pm 0.13^{\mathrm{d}}$ & $1.37 \pm 0.24^{\mathrm{e}}$ & $1.40 \pm 0.19^{\mathrm{e}}$ \\
SOD (U/mg of tissue proteins) & $1519 \pm 1.48^{\mathrm{a}}$ & $1078 \pm 1.08^{\mathrm{b}}$ & $1510 \pm 1.33^{\mathrm{a}}$ & $1120 \pm 0.94^{\mathrm{c}}$ & $1193 \pm 1.62^{\mathrm{d}}$ & $1276 \pm 1.29^{\mathrm{e}}$ \\
GPx (U/mg of tissue proteins) & $6.19 \pm 1.35^{\mathrm{a}}$ & $2.88 \pm 1.20^{\mathrm{b}}$ & $6.08 \pm 1.76^{\mathrm{a}}$ & $3.27 \pm 1.28^{\mathrm{c}}$ & $4.09 \pm 1.13^{\mathrm{d}}$ & $4.73 \pm 1.41^{\mathrm{e}}$ \\
CAT (U/mg of tissue proteins) & $1.07 \pm 0.54^{\mathrm{a}}$ & $0.54 \pm 0.33^{\mathrm{b}}$ & $1.04 \pm 0.49^{\mathrm{a}}$ & $0.62 \pm 0.23^{\mathrm{b}}$ & $0.86 \pm 0.41^{\mathrm{c}}$ & $1.01 \pm 0.35^{\mathrm{a}}$ \\
GSH (U/mg of tissue proteins) & $73.30 \pm 0.89^{\mathrm{a}}$ & $48.66 \pm 1.01^{\mathrm{b}}$ & $72.38 \pm 0.77^{\mathrm{a}}$ & $55.72 \pm 0.89^{\mathrm{c}}$ & $56.30 \pm 0.63^{\mathrm{c}}$ & $62.08 \pm 1.06^{\mathrm{d}}$ \\
\hline
\end{tabular}

Abbreviations: Fa, formaldehyde; SOD, superoxide dismutase; GPx, glutathione peroxidase; CAT, catalase

Different letters indicate significant differences $(P<0.05)$ between groups. Values represent means \pm SEM $(N=8)$.

Table 4. Comparison of MDA in different groups

\begin{tabular}{lllllll}
\hline Groups & Control & FA & Sham & Ginger 0.5 + FA & Ginger 1 + FA & Ginger 2+ FA \\
\hline MDA $\left(\mu \mathrm{mol}^{\circ} \mathrm{mg}^{-1}\right)$ & $2.74 \pm 1.22^{\mathrm{a}}$ & $7.23 \pm 1.37^{\mathrm{b}}$ & $2.81 \pm 1.09^{\mathrm{a}}$ & $6.85 \pm 1.30^{\mathrm{c}}$ & $5.79 \pm 0.89^{\mathrm{d}}$ & $4.38 \pm 1.32^{\mathrm{e}}$ \\
\hline
\end{tabular}

Abbreviation: MDA, malondialdehyde.

Different letters indicate significant differences $(P<0.05)$ between groups. Values represent means \pm SEM $(N=8)$. 
Table 5. The mean of expression of $\mathrm{Bcl}-2$ and Bax genes between treated groups relative to reference gene

\begin{tabular}{lcccccc}
\hline Gene & Control & FA & Sham & Ginger 0.5 + FA & Ginger 1 + FA \\
\hline$B c l-2$ & $0.83 \pm 0.16^{\mathrm{a}}$ & $0.16 \pm 0.07^{\mathrm{b}}$ & $0.82 \pm 0.20^{\mathrm{a}}$ & $0.41 \pm 0.38^{\mathrm{c}}$ & $0.62 \pm 0.26^{\mathrm{d}}$ & $0.63 \pm 0.17^{\mathrm{d}}$ \\
$B a x$ & $0.53 \pm 0.28^{\mathrm{a}}$ & $2.38 \pm 0.93^{\mathrm{b}}$ & $0.52 \pm 0.21^{\mathrm{a}}$ & $2.15 \pm 1.54^{\mathrm{c}}$ & $1.59 \pm 1.41^{\mathrm{d}}$ & $1.02 \pm 0.37^{\mathrm{e}}$ \\
\hline
\end{tabular}

Abbreviation: Fa, formaldehyde.

Different letters indicate significant differences $(P<0.05)$ between groups. Values represent means \pm SEM $(N=8)$.

$18 S R R A$ gene was used as the reference gene.

stimulates Leydig cells to release testosterone (40). As mentioned above, FA degenerates Leydig cells, therefore it results in reduction of testosterone $(6,33)$. Lower levels of testosterone negatively influence spermatogenesis and it can lead to improper functioning of Sertoli cells (41). FSH and testosterone's regulation of spermatogenesis occurs by the activity of these hormones on the Sertoli cells. Due to the importance of testosterone for spermatogenesis, FSH leads to an increase in spermatogenic output by increasing Sertoli cells (42). Ozen et al (13) suggests that testosterone reduction is result of the improper activity of $\mathrm{GnRH}$ neurons in hypothalamus- hypophyseal-gonadal axis due to FA administration. FA may cause olfactory bulb connections to transmit inhibitory signals to the neurons at hypothalamus and/or anterior pituitary levels. According to Sari et al (43), being exposed to low concentrations of FA influences hypothalamus- hypophyseal-adrenal (HPA) axis.

This research showed that co-administration of Ginger with FA incremented the levels of LH, FSH and testosterone. These results are in line with previous reports $(11,18,19,37,39)$. It is probably due to antioxidant and androgenic properties.

In this study, FA lowered TAC level and the activities of antioxidants such as SOD, CAT, GPx, and GSH which are responsible for scavenging ROS in the male reproductive system (44). FA also increased lipid peroxidation in testis tissue. Sperm plasma membrane is susceptible to the lipid peroxidation because it has high polyunsaturated fatty acid content (45). The results obtained in this paper are consistent with other researches $(9,10,12,46)$ which reported that FA administration induced oxidative stress in testis tissue. Based on the results, administration of Ginger reduced oxidative stress by improving TAC, SOD, CAT, GPX, and GSH activity. Furthermore, it led to the reduction of lipid peroxidation in the testes. These findings have been proved by previous studies $(11,18,38,47)$.

As a pro-apoptotic protein, Bax leads to mitochondrial membrane release of cytochrome $\mathrm{C}$ into cytoplasm which results in activation of caspase and starting of apoptosis process. Bcl-2 prevents the insertion of Bax into the mitochondrial membrane. Therefore, it inhibits release of cytochrome $\mathrm{C}$ and as a result prevents apoptosis process (9). Real-time PCR delineated that FA decreased Bcl-2 gene expression and increased expression of Bax gene in mice testes. These findings support the results obtained by Özen et al (9) which showed exposure to FA induces apoptosis in the spermatogenic and Leydig cells. Thereby, it can be concluded that FA reduced spermatogenesis probably by induction of apoptosis in spermatogenic germ cells. Co-administration of Ginger with FA downregulated $B a x$ and up-regulated $B c l-2$ genes expression. These results confirm anti-apoptotic effects of Ginger which reported in previous studies (47-49).

\section{Conclusion}

This paper investigated the ameliorative effects of Ginger on FA induced oxidative stress in male mice reproductive system. It is recommended that more researches be conducted on the relationship between the co-administration of Ginger with FA and gene expression such as apoptotic and testis-specific genes in male fertility. Based on this study, we suggest powerful anti-oxidants such as Ginger be added to the daily diet of people who are at risk of exposure to environmental toxic contaminants which cause oxidative stress in order to decrease the chance of infertility.

\section{Acknowledgements}

The authors would like to sincerely thank the members of the Faculty of Veterinary Medicine and Urmia University Research Council for the approval and support of this research protocol.

\section{Authors' contributions}

AS contributed in conception, design, data collection, statistical analysis and drafting of the manuscript. AS, MP, ND and MK, contributed in conception, design, supervision of the study and drafting of the manuscript. All authors approved the final version for submission.

\section{Conflict of interests}

The authors declare that there is no conflict of interest.

\section{Ethical Considerations}

The study was approved by Animal Ethics Committee in Urmia University, Urmia, Iran (AECVU-163-2018) and conducted under the regulations of this committee.

\section{Funding/Support}

This research has been financially supported by Research Council of Urmia University.

\section{References}

1. Martino-Andrade AJ, Chahoud I. Reproductive toxicity of phthalate esters. Mol Nutr Food Res. 2010;54(1):148-57. 
doi: $10.1002 / \mathrm{mnfr} .200800312$.

2. Campagna C, Guillemette C, Ayotte P, Bailey JL. Effects of an environmentally relevant organochlorine mixture and a metabolized extract of this mixture on porcine sperm parameters in vitro. J Androl. 2009;30(3):317-24. doi: 10.2164/jandrol.108.006478.

3. Golalipour MJ, Azarhoush R, Ghafari S, Gharravi AM, Fazeli SA, Davarian A. Formaldehyde exposure induces histopathological and morphometric changes in the rat testis. Folia Morphol (Warsz). 2007;66(3):167-71.

4. Formaldehyde, 2-butoxyethanol and 1-tert-butoxypropan2-ol. IARC Monogr Eval Carcinog Risks Hum. 2006;88:1478.

5. Pala M, Ugolini D, Ceppi M, Rizzo F, Maiorana L, Bolognesi C, et al. Occupational exposure to formaldehyde and biological monitoring of Research Institute workers. Cancer Detect Prev. 2008;32(2):121-6. doi: 10.1016/j. cdp.2008.05.003.

6. Vosoughi S, Khavanin A, Salehnia M, Asilian Mahabadi H, Shahverdi A, Esmaeili V. Adverse effects of formaldehyde vapor on mouse sperm parameters and testicular tissue. Int J Fertil Steril. 2013;6(4):250-67.

7. Tajaddini Mahani S, Behnam B, Abbassi M, Asgari H, Nazmara Z, Shirinbayan P, et al. Tsga10 expression correlates with sperm profiles in the adult formalin-exposed mice. Andrologia. 2016;48(10):1092-9. doi: 10.1111/and.12543.

8. Zhou DX, Qiu SD, Zhang J, Tian H, Wang HX. The protective effect of vitamin $\mathrm{E}$ against oxidative damage caused by formaldehyde in the testes of adult rats. Asian J Androl. 2006;8(5):584-8. doi: 10.1111/j.1745-7262.2006.00198.x.

9. Ozen OA, Kus MA, Kus I, Alkoc OA, Songur A. Protective effects of melatonin against formaldehyde-induced oxidative damage and apoptosis in rat testes: an immunohistochemical and biochemical study. Syst Biol Reprod Med. 2008;54(45):169-76. doi: 10.1080/19396360802422402.

10. Zhou D, Zhang J, Wang H. Assessment of the potential reproductive toxicity of long-term exposure of adult male rats to low-dose formaldehyde. Toxicol Ind Health. 2011;27(7):591-8. doi: 10.1177/0748233710393401.

11. Akinyemi AJ, Adedara IA, Thome GR, Morsch VM, Rovani MT, Mujica LKS, et al. Dietary supplementation of ginger and turmeric improves reproductive function in hypertensive male rats. Toxicol Rep. 2015;2:1357-66. doi: 10.1016/j.toxrep.2015.10.001.

12. Gules O, Eren U. The effect of xylene and formaldehyde inhalation on testicular tissue in rats. Asian-Australas J Anim Sci. 2010;23(11):1412-20. doi: 10.5713/ajas.2010.90519.

13. Ozen OA, Akpolat N, Songur A, Kus I, Zararsiz I, Ozacmak $\mathrm{VH}$, et al. Effect of formaldehyde inhalation on Hsp70 in seminiferous tubules of rat testes: an immunohistochemical study. Toxicol Ind Health. 2005;21(10):249-54. doi: 10.1191/0748233705th235oa.

14. Wong VC, Cash HL, Morse JL, Lu S, Zhitkovich A. S-phase sensing of DNA-protein crosslinks triggers TopBP1independent ATR activation and p53-mediated cell death by formaldehyde. Cell Cycle. 2012;11(13):2526-37. doi: 10.4161/cc.20905.

15. Jedlinska-Krakowska M, Bomba G, Jakubowski K, Rotkiewicz T, Jana B, Penkowski A. Impact of oxidative stress and supplementation with vitamins $\mathrm{E}$ and $\mathrm{C}$ on testes morphology in rats. J Reprod Dev. 2006;52(2):203-9.

16. Yang HS, Han DK, Kim JR, Sim JC. Effects of alphatocopherol on cadmium-induced toxicity in rat testis and spermatogenesis. J Korean Med Sci. 2006;21(3):445-51. doi: 10.3346/jkms.2006.21.3.445.

17. Ali BH, Blunden G, Tanira MO, Nemmar A. Some phytochemical, pharmacological and toxicological properties of ginger (Zingiber officinale Roscoe): a review of recent research. Food Chem Toxicol. 2008;46(2):409-20. doi: $\quad$ 10.1016/j.fct.2007.09.085.

18. Ghlissi Z, Atheymen R, Boujbiha MA, Sahnoun Z, Makni Ayedi F, Zeghal K, et al. Antioxidant and androgenic effects of dietary ginger on reproductive function of male diabetic rats. Int J Food Sci Nutr. 2013;64(8):974-8. doi: 10.3109/09637486.2013.812618.

19. Khaki A, Fathiazad F, Nouri M, Khaki AA, Ozanci C, Ghafari Novin M, et al. The effects of Ginger on spermatogenesis and sperm parameters of rat. Iran J Reprod Med. 2009;7(1):7-12.

20. Morakinyo AO, Adeniyi OS, Arikawe AP. Effects of Zingiber Officinale on reproductive functions in the male rat. Afr J Biomed Res. 2008;11(3):329-34. doi: 10.4314/ajbr. v11i3.50750.

21. Rong X, Peng G, Suzuki T, Yang Q, Yamahara J, Li Y. A 35-day gavage safety assessment of ginger in rats. Regul Toxicol Pharmacol. 2009;54(2):118-23. doi: 10.1016/j. yrtph.2009.03.002.

22. World Health Organization, Department of Reproductive Health and Research. WHO laboratory manual for the examination and processing of human semen. WHO Press; 2010:287.

23. Wyrobek AJ, Gordon LA, Burkhart JG, Francis MW, Kapp RW Jr, Letz G, et al. An evaluation of the mouse sperm morphology test and other sperm tests in nonhuman mammals. A report of the U.S. Environmental Protection Agency Gene-Tox Program. Mutat Res. 1983;115(1):1-72.

24. Krassas GE, Papadopoulou F, Tziomalos K, Zeginiadou T, Pontikides N. Hypothyroidism has an adverse effect on human spermatogenesis: a prospective, controlled study. Thyroid. 2008;18(12):1255-9. doi: 10.1089/thy.2008.0257.

25. Talebi AR, Sarcheshmeh AA, Khalili MA, Tabibnejad N. Effects of ethanol consumption on chromatin condensation and DNA integrity of epididymal spermatozoa in rat. Alcohol. 2011;45(4):403-9. doi: 10.1016/j. alcohol.2010.10.005.

26. Loraine JA, Bell ET. Hormone assays and their clinical application. Edinburgh, UK: E. \& S. Pub. Livingstone; 1971.

27. Benzie IF, Strain JJ. Ferric reducing/antioxidant power assay: direct measure of total antioxidant activity of biological fluids and modified version for simultaneous measurement of total antioxidant power and ascorbic acid concentration. Methods Enzymol. 1999;299:15-27.

28. Rajesh MG, Latha MS. Protective activity of Glycyrrhiza glabra Linn. on carbon tetrachloride-induced peroxidative damage. Indian J Pharmacol. 2004;36(5):284-7.

29. Nishikimi M, Appaji N, Yagi K. The occurrence of superoxide anion in the reaction of reduced phenazine methosulfate and molecular oxygen. Biochem Biophys Res Commun. 1972;46(2):849-54.

30. Paglia DE, Valentine WN. Studies on the quantitative and 
qualitative characterization of erythrocyte glutathione peroxidase. J Lab Clin Med. 1967;70(1):158-69.

31. Sinha AK. Colorimetric assay of catalase. Anal Biochem. 1972;47(2):389-94. doi: 10.1016/0003-2697(72)90132-7.

32. Xie B, Qin Z, Huang B, Xie T, Yao H, Wei Y, et al. In vitro culture and differentiation of buffalo (Bubalus bubalis) spermatogonia. Reprod Domest Anim. 2010;45(2):275-82. doi: 10.1111/j.1439-0531.2008.01281.x.

33. Khalil SR, Awad A, Ali SA. Melamine and/or formaldehyde exposures affect steroidogenesis via alteration of StAR protein and testosterone synthetic enzyme expression in male mice. Environ Toxicol Pharmacol. 2017;50:136-44. doi: 10.1016/j.etap.2017.01.018.

34. Betancourt-Martinez ND, Jimenez-Villarreal J, CarranzaRosales P, Guzman-Delgado NE, Leyva Orasma C, Viveros Valdez E, et al. Sperm chromatin dispersion by formaldehyde in Wistar rats. Genet Mol Res. 2015;14(3):10816-26. doi: 10.4238/2015.September.9.20.

35. Han SP, Zhou DX, Lin P, Qin Z, An L, Zheng LR, et al. Formaldehyde exposure induces autophagy in testicular tissues of adult male rats. Environ Toxicol. 2015;30(3):32331. doi: 10.1002/tox.21910.

36. Henkel R, Maass G, Schuppe HC, Jung A, Schubert J, Schill WB. Molecular aspects of declining sperm motility in older men. Fertil Steril. 2005;84(5):1430-7. doi: 10.1016/j. fertnstert.2005.05.020.

37. Shalaby MA, Hamowieh AR. Safety and efficacy of Zingiber officinale roots on fertility of male diabetic rats. Food Chem Toxicol. 2010;48(10):2920-4. doi: 10.1016/j.fct.2010.07.028.

38. Mohammadi F, Nikzad H, Taghizadeh M, Taherian A, Azami-Tameh A, Hosseini SM, et al. Protective effect of Zingiber officinale extract on rat testis after cyclophosphamide treatment. Andrologia. 2014;46(6):6806. doi: 10.1111/and.12135.

39. Moselhy WA, Helmy NA, Abdel-Halim BR, Nabil TM, Abdel-Hamid MI. Role of ginger against the reproductive toxicity of aluminium chloride in albino male rats. Reprod Domest Anim. 2012;47(2):335-43. doi: 10.1111/j.14390531.2011.01878.x.

40. Sarkar R, Mohanakumar KP, Chowdhury M. Effects of an organophosphate pesticide, quinalphos, on the hypothalamo-pituitary-gonadal axis in adult male rats. J Reprod Fertil. 2000;118(1):29-38.

41. Yoshida S, Hiyoshi K, Ichinose T, Takano H, Oshio S, Sugawara I, et al. Effect of nanoparticles on the male reproductive system of mice. Int J Androl. 2009;32(4):33742. doi: 10.1111/j.1365-2605.2007.00865.x.

42. Griswold MD. The central role of Sertoli cells in spermatogenesis. Semin Cell Dev Biol. 1998;9(4):411-6. doi: $\quad$ 10.1006/scdb.1998.0203.

43. Sari DK, Kuwahara S, Tsukamoto Y, Hori H, Kunugita $\mathrm{N}$, Arashidani K, et al. Effect of prolonged exposure to low concentrations of formaldehyde on the corticotropin releasing hormone neurons in the hypothalamus and adrenocorticotropic hormone cells in the pituitary gland in female mice. Brain Res. 2004;1013(1):107-16. doi: 10.1016/j. brainres.2004.03.070.

44. Fujii J, Iuchi Y, Matsuki S, Ishii T. Cooperative function of antioxidant and redox systems against oxidative stress in male reproductive tissues. Asian J Androl. 2003;5(3):23142.

45. Aitken RJ. Free radicals, lipid peroxidation and sperm function. Reprod Fertil Dev. 1995;7(4):659-68.

46. Duong A, Steinmaus C, McHale CM, Vaughan CP, Zhang L. Reproductive and developmental toxicity of formaldehyde: a systematic review. Mutat Res. 2011;728(3):118-38. doi: 10.1016/j.mrrev.2011.07.003.

47. Amin A, Hamza AA, Kambal A, Daoud S. Herbal extracts counteract cisplatin-mediated cell death in rat testis. Asian J Androl. 2008;10(2):291-7. doi: 10.1111/j.17457262.2008.00379.x.

48. Zahedi A, Fathiazad F, Khaki A, Ahmadnejad B. Protective effect of ginger on gentamicin-induced apoptosis in testis of rats. Adv Pharm Bull. 2012;2(2):197-200. doi: 10.5681/ apb.2012.030.

49. Sakr SA, Al-Amoudi WM. Effect of ginger extract on deltamethrin induced histomorphological and immunohistochemical changes in testes of albino rats. Life Sci J. 2012;9(1):771-8. 